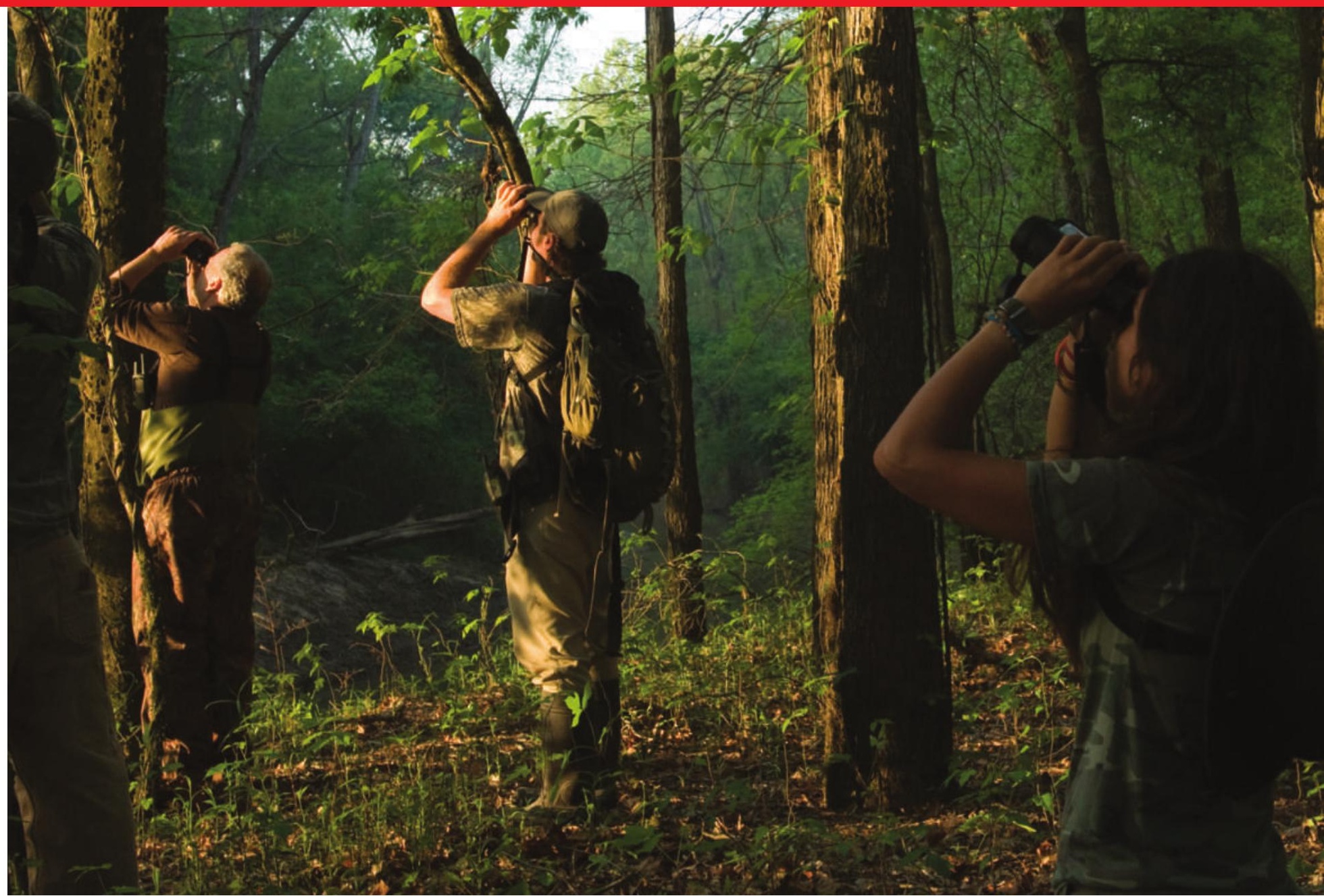

\title{
Still looking for that woodpecker
}

An expensive recovery plan to save the ivory-billed woodpecker from extinction may come decades too late.

Nearly five years after biologists thrilled the conservation world by saying that they had videotaped the elusive ivory-billed woodpecker, the US Fish and Wildlife Service (FWS) is on the verge of approving a final recovery plan to manage the species. The plan will lay out a conservation strategy, including what habitat should be preserved - all for a bird that many prominent ornithologists have given up on.

In 2005, a team reported ${ }^{1}$ videotaping an ivory-billed woodpecker (Campephilus principalis) in eastern Arkansas, in what seemed to be the first documented sighting of a creature thought to have become extinct at least 50 years earlier ${ }^{2}$. Other experts have challenged the claim $^{3}$, although the team members maintain that they spotted one bird ${ }^{4}$.

But after five years of fruitless searching, hopes of saving the species have faded. "We don't believe a recoverable population of ivory-billed woodpeckers exists," says Ron Rohrbaugh, a conservation biologist at Cornell University in Ithaca, New York, who headed the original search team.

The FWS has spent $\$ 14$ million trying to document and conserve the ivory-billed woodpecker throughout the southeast United States, including $\$ 8$ million for habitat preservation and $\$ 2$ million for search-associated costs. The hunt was suspended last October after it ran out of money. Chasing down a string of dubious and faked claims of sightings added an extra burden, undermining already-stressed wildlife programmes, experts say.

Jerome Jackson, an ornithologist at Florida Gulf Coast University in Fort Myers who serves on the FWS's ivory-billed woodpecker recovery team, says that a draft recovery plan from 2007 is "incredibly biased". In his view, the plans have overemphasized evidence of the bird's existence to shore up

"We don't believe
a recoverable
population exists."

Rohrbaugh and others have continued to publish ${ }^{5-7}$ on the likelihood of the woodpecker's existence. One study concluded that if there was just one surviving ivory-billed woodpecker in the area of Arkansas searched, the team had a $12 \%$ chance of finding it. The FWS recovery plan is meant to consider such estimates.

Along the way there have been plenty of false hopes. Last spring, avian ecologist Jeff Hoover was trying to verify a photo said to be of an ivory-billed woodpecker in the Cache River State Natural Area in southern Illinois. But as Hoover, of the Illinois Natural History Survey in Champaign, was studying the photo, the person responsible for political support for saving it. "I don't think I'm going to be happy with the final plan either," he adds.

Laurie Fenwood, coordinator of the ivorybilled woodpecker project at the agency's office in Atlanta, Georgia, says that recovery plans are needed to collect the best scientific knowledge on species - even if it's not clear whether they have already gone extinct. it confessed that the photo was faked.

Steve Sheridan, a graphic artist in Lexington, Kentucky, says that he did see an ivory-billed woodpecker in the region, and created the photo to encourage conservation of the area.

"I told him the effect could be the exact opposite, setting back restoration for years," says Hoover.

Other sighting reports continue to meet 
